\title{
A low-Mr lipase activation factor cooperating with lipase modulator protein LimL in Pseudomonas sp. strain 109
}

\author{
Junko Tanaka, ${ }^{1}$ Fumio Ihara, ${ }^{2}$ Takuya Nihira ${ }^{1}$ and Yasuhiro Yamada ${ }^{1}$
}

Author for correspondence: Takuya Nihira. Tel: +81668797433 . Fax: +81668797432.

e-mail: nihira@biochem.bio.eng.osaka-u.ac.jp

\footnotetext{
1 Department of Biotechnology, Graduate School of Engineering, Osaka University, 2-1 Yamadaoka, Suita, Osaka 565-0871, Japan

2 Department of Plant Protection, National Institute of Fruit Tree Science, 2-1 Fujimoto, Tsukuba, Ibaraki 305-8605, Japan
}

\begin{abstract}
Pseudomonas sp. strain 109 produces a unique lipase (LipL) which efficiently catalyses intramolecular transesterification of $\omega$-hydroxyesters to form macrocyclic lactones. In vivo production of enzymically active LipL requires lipase modulator protein (LimL), which functions as a molecular chaperone for the correct folding of LipL. However, previous work has shown that LipL forms a tight complex with LimL in vitro and the resulting LipL-LimL complex is only partially active, suggesting an additional mechanism that facilitates the dissociation of the complex to form enzymically active LipL. In the present work, a low- $M_{r}$ compound (lipase activation factor, LAF) was found in Pseudomonas sp. strain 109 that when added to the LipL-LimL complex resulted in the activation of LipL. $\mathrm{Ca}^{2+}$ ions also enhanced lipase activity, but the instantaneous activation by $\mathrm{Ca}^{2+}$ was different from the gradual and timedependent activation by LAF, indicating the novel nature of this compound. LAF passed through an ultrafiltration membrane with an $M_{r}$ cut-off of 3000 and showed an apparent $M_{\mathrm{r}}$ of $\mathbf{3 3 0} \pm \mathbf{3 0}$ on Superdex Peptide gel-filtration chromatography. Treatment of the LipL-LimL complex with LAF liberated free active LipL, indicating that LAF was necessary to dissociate the LipL-LimL complex.
\end{abstract}

Keywords: Pseudomonas, lactonizing lipase, lipase activation factor, lipase modulator protein

\section{INTRODUCTION}

Lipase (EC 3.1.1.3), a lipolytic enzyme that catalyses the hydrolysis of triglycerides, is widely distributed in organisms from animals to bacteria. In addition to the stereoselective hydrolysis of esters in the presence of water, lipase can catalyse transesterification, esterification and aminolysis (Zaks \& Klibanov, 1984), and also oximolysis (Zaks \& Klibanov, 1985), under anhydrous conditions; this makes lipases very useful catalysts in several aspects of organic synthesis (Wong \& Whitesides, 1994). Although many lipases of different origins are available, lipases from Pseudomonas are very useful for organic synthesis. We previously established that an extracellular lipase (LipL) of Pseudomonas sp. strain 109 catalyses the intramolecular transesterification of $\omega$-hydroxyesters in an anhydrous organic solvent, leading to the efficient formation of 14- to 20membered lactones (Ihara et al., 1991; Makita et al.,

Abbreviation: LAF, lipase activation factor.
1987). Lactones consisting of 13 or more carbons (macrocyclic lactones) are the key structures of many useful compounds, such as macrolide antibiotics (KellerSchierlein, 1973). However, the chemical cyclization of linear precursors into macrocyclic lactones is not straightforward, and usually requires very complicated, often very expensive, reagents or else drastic cyclization conditions. Because LipL-mediated cyclization is easy and straightforward and can be done under very mild conditions, LipL may become a good alternative for the synthesis of macrocyclic lactones, provided that sufficient pure LipL is easily available. Furthermore, development of an effective procedure for producing large amounts of recombinant LipL is also essential for protein engineering leading to more useful forms of LipL.

The gene (lipL) encoding the lactonizing lipase has already been cloned in our laboratory from strain 109 , and the amino acid sequence was deduced from the nucleotide sequence (Ihara et al., 1991). However, the lipL gene alone was not sufficient to produce active 
LipL. The co-existence of a downstream $\operatorname{limL}$ gene, either on the same plasmid or on a separate plasmid, was found to be essential for the functional expression of LipL (Ihara et al., 1992). A similar requirement of a secondary gene has been observed for several lipases (Frenken et al., 1993a; Iizumi et al., 1991; Jørgensen et al., 1991; Kok et al., 1995; Ogierman et al., 1997; Siomi et al., 1992; Wohlfarth \& Winkler, 1992), and studies of Burkholderia cepacia (LimA; Hobson et al., 1993), Pseudomonas glumae (LipB; Frenken et al., 1993b), Pseudomonas aeruginosa (LipB; Hirayama et al., 1993) and Pseudomonas sp. strain KWI-56 (Act; Iizumi \& Fukase, 1994) suggested that the secondary gene product is required for correct lipase folding.

When recombinant LipL (rLipL) and recombinant LimL (rLimL) were overexpressed in Escherichia coli, $\mathrm{rLimL}$ was formed as a soluble protein but rLipL was obtained as inactive inclusion bodies. In vitro renaturation experiments with rLipL inclusion bodies in the presence of urea revealed that rLimL was essential to obtain soluble and active rLipL (Ihara et al., 1995). However, the renatured rLipL showed only $6 \%$ of the activity observed in native and fully active LipL, due to the formation of a tight complex between rLipL and rLimL as detected by immunoprecipitation (Ihara et al., 1995). This suggests that bound rLimL inhibits hydrolytic activity of rLipL and that some additional mechanism exists that facilitates LimL dissociation. To obtain fully active LipL in large amounts, it is essential to devise an efficient reactivation procedure for the inclusion bodies of rLipL, because the amount of native LipL that can be obtained in Pseudomonas sp. strain 109 is low.

In this study, we found a novel lipase-activating factor (LAF) in Pseudomonas sp. strain 109. This factor synergistically acted with $\mathrm{Ca}^{2+}$ on the rLipL-rLimL complex to increase lipase activity $1 \cdot 8$-fold, and was found to be a novel low- $M_{\mathrm{r}}$ compound $\left(M_{\mathrm{r}} 330 \pm 30\right)$. The increase of lipase activity was confirmed to be associated with the release of free rLipL from the rLipL-rLimL complex.

\section{METHODS}

Bacterial strains, plasmids and media. Pseudomonas sp. strain 109, a LipL producer (Ihara et al., 1991) (strain FERM-P no. 3025, the Fermentation Research Institute, Agency of Industrial Science and Technology, Japan), was used as the source of lipase activation factor throughout this study. E. coli

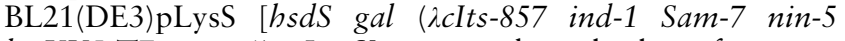
lacUV5-T7 gene 1) pLysS] was used as the host for overexpression of lipL and limL genes from the pET-3d (Studier et al., 1990) based vectors pETY402 (Ihara et al., 1995) and pLIM413 (Ihara et al., 1995), respectively.

Preparation of crude cell-free lysate of Pseudomonas sp. strain 109 and fractionation by ultrafiltration. Pseudomonas sp. strain 109 was grown in $250 \mathrm{ml} \mathrm{LB}$ medium in a $500 \mathrm{ml}$ Sakaguchi flask at $30^{\circ} \mathrm{C}$ and 120 r.p.m. for about $12 \mathrm{~h}$ to an $\mathrm{OD}_{600}$ of $2 \cdot 5$. Cells were harvested by centrifugation $(3000 \mathrm{~g}$, $10 \mathrm{~min}, 4^{\circ} \mathrm{C}$ ), suspended in $5 \mathrm{ml} 50 \mathrm{mM}$ potassium phosphate buffer $(\mathrm{pH} 6 \cdot 5)$ and sonicated $\left(4 \times 30 \mathrm{~s}, 4^{\circ} \mathrm{C}\right)$. Cell debris was removed by centrifugation $\left(10000 \mathrm{~g}, 20 \mathrm{~min}, 4^{\circ} \mathrm{C}\right)$, and the supematant was used as crude cell-free lysate and stored at $-80^{\circ} \mathrm{C}$ until use.

To fractionate the crude cell-free lysate by $M_{r}$, the lysate was either dialysed with a cellulose dialysis membrane (Wako Pure Chemical) against a 100 -fold volume of $50 \mathrm{mM}$ potassium phosphate buffer $(\mathrm{pH} 6.5)$ for $12 \mathrm{~h}$ at $4{ }^{\circ} \mathrm{C}$, or filtered through a Centriprep $3\left(M_{\text {r }}\right.$ cut $\left.\geqslant 3000\right)$ or Centriprep $30\left(M_{\text {r }}\right.$ cut $\geqslant 30000$, Amicon). The filtrates from the ultrafiltrations were referred to as $<3000$ lysate and $<30000$ lysate, respectively.

Renaturation of recombinant LipL (rLipL). rLipL and recombinant LimL (rLimL) were overexpressed from plasmids pETY402 and pLIM413, respectively, in E. coli, using an LB medium containing $1 \%(\mathrm{w} / \mathrm{v})$ glucose, $10 \mu \mathrm{g}$ ampicillin $\mathrm{ml}^{-1}$ and $2 \mu \mathrm{g}$ chloramphenicol $\mathrm{ml}^{-1}$, purified as described previously (Ihara et al., 1995), and stored at $-80^{\circ} \mathrm{C}$ until use. For obtaining the rLipL-rLimL complex, purified inclusion bodies of rLipL $(0.5 \mathrm{mg})$ were solubilized in $1 \mathrm{ml} 6 \mathrm{M}$ urea. After $1 \mathrm{~h}$ incubation at room temperature, $\mathrm{rLimL}(1.15 \mathrm{mg}$ in $50-100 \mu \mathrm{l}$, two equivalents of rLipL) was added to the solubilized rLipL, and the solution was made up to $5 \mathrm{ml}$ with $6 \mathrm{M}$ urea. The solubilized mixture of rLipL and rLimL was renatured by decreasing the urea concentration in a stepwise manner from 4 to $0 \mathrm{M}$ by successive dialyses against $500 \mathrm{ml} 50 \mathrm{mM}$ potassium phosphate buffer $(\mathrm{pH} 6.5)$ containing $2 \mathrm{M}$ urea for $3 \mathrm{~h}$ at $4{ }^{\circ} \mathrm{C}$ and two changes of $500 \mathrm{ml} 50 \mathrm{mM}$ potassium phosphate buffer ( $\mathrm{pH} \mathrm{6.5)} \mathrm{for} 3 \mathrm{~h}$.

Gel-filtration HPLC. HPLC was performed with a JASCO model Tri Rotor- $\mathrm{V}$ equipped with a UV detector (JASCO UVIDEC-100-V). The $<3000$ lysate $(250 \mu \mathrm{l})$ was applied at room temperature onto a Superdex Peptide HR 10/30 column $(1.0 \times 30 \mathrm{~cm}$, Pharmacia Blotech $)$ pre-equilibrated with $50 \mathrm{mM}$ potassium phosphate buffer $(\mathrm{pH} 6 \cdot 5)$ containing $0 \cdot 2 \mathrm{M}$ $\mathrm{NaCl}$. The $<3000$ lysate was then fractionated from the column with the same buffer at a flow rate of $0.5 \mathrm{ml} \mathrm{min}^{-1}$ and collected in $200 \mu \mathrm{l}$ fractions.

Gel-filtration on a SMART system. Gel-filtration of rLipLrLimL complexes was performed using a SMART system (Pharmacia Biotech). The rLipL-rLlmL complex, either without treatment or activated by LAF, was injected into a Superose12 PC $3 \cdot 2 / 30(0 \cdot 32 \times 30 \mathrm{~cm}$, Pharmacia Biotech $)$ gelfiltration column equilibrated with $50 \mathrm{mM}$ potassium phosphate buffer ( $\mathrm{pH} 6.5$ ) containing $0 \cdot 2 \mathrm{M} \mathrm{NaCl}$ and $0.1 \%(\mathrm{w} / \mathrm{v})$ NoigenHC at a flow rate of $25 \mu \mathrm{min}^{-1}$. Protein elution was monitored by absorbance at $280 \mathrm{~nm}$ and the eluate was fractionated at room temperature into portions of $25 \mu \mathrm{l}$.

Western blot analysis. The fractions ( $5 \mu \mathrm{l}$ samples) from gelfiltration on the SMART system were directly applied to SDSPAGE after boiling in the presence of $1 \%$ SDS, and Western blot analysis was carried out by using the ECL Western blotting detection kit (Amersham Life Science) under conditions recommended by the manufacturer. Polyclonal antirLipL or anti-rLimL antibodies have been described previously (Ihara et al., 1995). Immunoreactive proteins on Western blots were visualized by the use of horseradish-peroxidase-conjugated anti-rabbit IgG (Amersham Life Science).

Lipase activation assay for LAF. A typical activation mixture $(100 \mu \mathrm{l})$ contained $0.05 \mathrm{M}$ potassium phosphate $(\mathrm{pH} 6.5), 3 \mu \mathrm{g}$ of the solubilized rLipL-rLimL complex, Pseudomonas cellfree lysate, and/or other factors as indicated. Reactions were initiated by the addition of cell-free lysate containing LAF. Samples $(10 \mu \mathrm{l})$ were withdrawn at appropriate times, mixed with $90 \mu \mathrm{l}$ potassium phosphate buffer ( $\mathrm{pH} 6.5$ ), and assayed for lipase activity. Each experiment was repeated at least three times, and data are expressed as means of triplicate experi- 
ments with all samples. Deviation in the activation by LAF was within $\pm 10 \%$.

Enzyme and protein assay. Lipase activity was routinely assayed by measuring the amount of $p$-nitrophenol formed from $p$-nitrophenyl hexanoate. The substrate $(5 \mathrm{mM} p$ nitrophenyl hexanoate) was emulsified completely by sonication in the presence of $0.5 \%(\mathrm{w} / \mathrm{v})$ Triton X-100 in $50 \mathrm{mM}$ potassium phosphate buffer ( $\mathrm{pH} \mathrm{6.5)} \mathrm{containing} 1 \mathrm{mM} \mathrm{MgCl}_{2}$. After preincubation of the enzyme solution $(1.5 \mathrm{ml})$ in the same buffer at $37^{\circ} \mathrm{C}$ for $1 \mathrm{~min}$, reactions were initiated by the addition of an equal volume of the substrate solution, followed by further incubation at $37^{\circ} \mathrm{C}$ for $10 \mathrm{~min}$. Reactions were terminated by the addition of ethanol $(3 \mathrm{ml})$, and the absorbance at $400 \mathrm{~nm}$ was measured. One unit of lipase activity was defined as the amount of enzyme which liberates $1 \mu \mathrm{mol} p$-nitrophenol $\mathrm{min}^{-1}$. Protein concentration was determined by a dye-binding assay (Protein Assay Kit; Bio-Rad) with bovine serum albumin as the standard.

\section{RESULTS AND DISCUSSION}

\section{Effect of various factors on the activation of rLipL-rLimL complex}

The presence of rLimL was essential to obtain lipase activity during the in vitro renaturation of purified $\mathrm{rLipL}$ inclusion bodies. However, the specific activity was only $6 \%$ of that of the corresponding amount of native lipase, and the renatured rLipL was found to be bound to rLimL (Ihara et al., 1995). Therefore, we suspect that dissociation of rLimL is necessary to obtain a fully active enzyme. We found that native LipL lost its activity by binding with rLimL, reaching a plateau of $40 \%$ residual activity by binding $2 \mathrm{~mol}$ rLimL per $1 \mathrm{~mol}$ LipL. However, because the complex was very tight, it was not possible to liberate LipL from the complex under simple in vitro conditions (data not shown). This difficulty of spontaneous dissociation suggests the presence of additional component(s) in Pseudomonas sp. strain 109 that facilitate(s) the dissociation. By liberating fully active rLipL, the dissociation should theoretically result in a 2.5-fold increase of lipase activity from the rLipL-rLimL complex.

To investigate the possibility that another factor, of either high or low $M_{r}$, was required for the activation of the rLipL-rLimL complex, we tested several compounds for their ability to enhance lipase activity from the solubilized rLipL-rLimL complex. Immediately after the addition of $1 \mathrm{mM} \mathrm{CaCl}$, lipase activity was enhanced 1.7-fold, while $1 \mathrm{mM}$ ATP or other divalent metal ions ( $1 \mathrm{mM} \mathrm{MgCl}, 1 \mathrm{mM} \mathrm{ZnCl} 2,1 \mathrm{mM} \mathrm{FeCl}_{3}$ ) were either inhibitory or had no effect. Because $\mathrm{Ca}\left(\mathrm{NO}_{3}\right)_{2}$ was similarly effective in enhancing lipase activity (data not shown), $\mathrm{Ca}^{2+}$ was concluded to be an effective component. Addition of Pseudomonas crude cell-free extract resulted in a small increase in activity at $0 \mathrm{~h}$, but after incubation at $4{ }^{\circ} \mathrm{C}$ for $24 \mathrm{~h}$, lipase activity increased about $1 \cdot 8$-fold, suggesting that some novel component(s) were present in the lysate. A similar level of activation (1.4-fold) was observed when native LipL was treated similarly after denaturation with $6 \mathrm{M}$ urea. To discriminate between the activation by $\mathrm{Ca}^{2+}$ and that by the lysate, the time-course of activation was com-

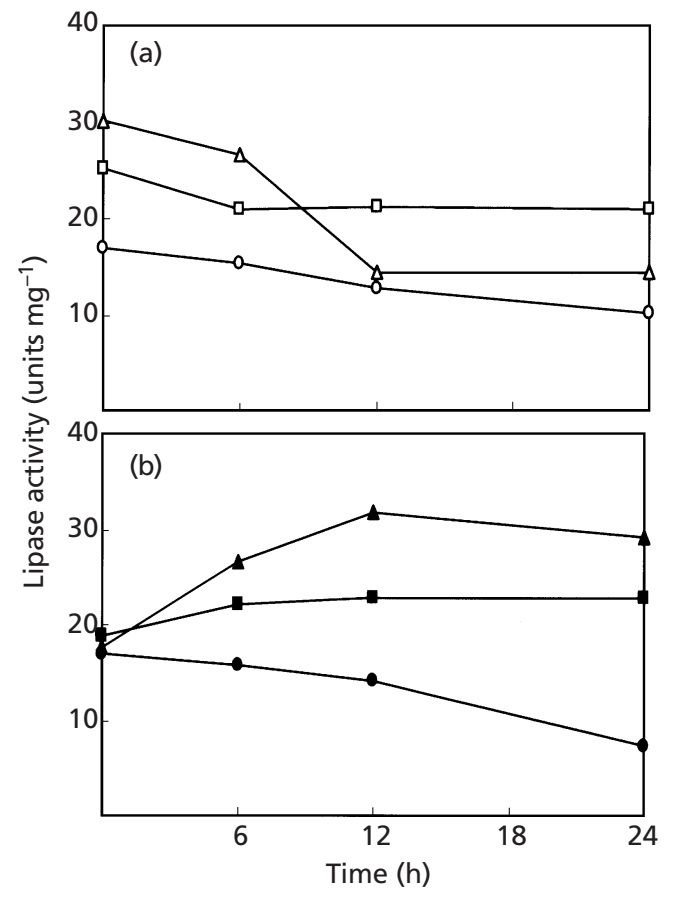

Fig. 1. Increase of lipase activity during incubation of rLipL-rLimL complex at $4{ }^{\circ} \mathrm{C}$ in the presence of (a) $\mathrm{CaCl}_{2}$ at $0 \mathrm{mM}(\bigcirc), 1 \mathrm{mM}(\square)$ or $5 \mathrm{mM}(\triangle)$, and (b) Pseudomonas cell lysate at $0 \mu \mathrm{l}(\mathbf{O}), 5 \mu \mathrm{l}(\boldsymbol{\square})$ or $25 \mu \mathrm{l}(\boldsymbol{\Delta})$. One microlitre of the cell lysate contained $60 \mu \mathrm{g}$ protein.

pared in the presence of $\mathrm{Ca}^{2+}$ or the lysate (Fig. 1). The effect of $\mathrm{Ca}^{2+}$ was instantaneous and concentration dependent, but the enhanced activity gradually decreased after a $24 \mathrm{~h}$ incubation, reaching $47-83 \%$ of that at $0 \mathrm{~h}$ (Fig. 1a). The effect of the lysate was also concentration dependent, but in this case the activation proceeded gradually with time until $24 \mathrm{~h}$ (Fig. 1b), indicating clearly that the action of the LAF in the lysate was different from that of $\mathrm{Ca}^{2+}$. Atomic absorption spectroscopy indicated that the crude cell-free lysate contained only $70 \mu \mathrm{M} \mathrm{Ca}^{2+}$. Because at least $0.5 \mathrm{mM}$ $\mathrm{Ca}^{2+}$ was necessary to see the activation, $70 \mu \mathrm{M} \mathrm{Ca}^{2+}$ could not account for the activation by the lysate; this suggested that the LAF is not $\mathrm{Ca}^{2+}$. Activation by the lysate was faster at higher temperatures $(1 \cdot 8$-fold increase after $2 \mathrm{~h}$ at $30^{\circ} \mathrm{C}$ or after $24 \mathrm{~h}$ at $4{ }^{\circ} \mathrm{C}$ ), although longer incubation at higher temperatures caused gradual loss of lipase activity due to thermal inactivation. To facilitate the reaction, we chose to perform activation by LAF at $30^{\circ} \mathrm{C}$ in the following studies.

\section{Characteristics of LAF}

To gain insight into the structure of LAF, the crude cellfree extract was dialysed using a cellulose membrane. The dialysed sample did not show any activation, suggesting that LAF is a low $-M_{\mathrm{r}}$ compound that passes through the dialysis membrane. No lipase-activation activity was detected in the outer solution, although at least 20 -fold volume of dialysis buffer was necessary to 


\section{Table 1. Characterization of LAF}

Filtrate from $M_{\mathrm{r}} \geqslant 3000$ ultrafiltration ( $<3000$ lysate) was treated as indicated and assayed for its ability to activate the rLipL-rLimL complex after $2 \mathrm{~h}$ incubation at $30^{\circ} \mathrm{C}$. One unit of each enzyme was used to treat the $<3000$ lysate at $37^{\circ} \mathrm{C}$ for $30 \mathrm{~min}$. For $\mathrm{pH}$ stability, the $<3000$ lysate was mixed with an equal volume of $2 \mathrm{M} \mathrm{NaOH}$ or $2 \mathrm{M} \mathrm{HCl}$. The solution was left for $60 \mathrm{~min}$ at $37^{\circ} \mathrm{C}$, neutralized, and then added to the rLipL-rLimL complex. Similarly diluted lysate was used as a control. Heat treatment of the lysate was done in a boiling water bath for $10 \mathrm{~min}$. All samples containing lysate contained $5 \mu \mathrm{l}$ cell-free lysate per $3 \mu \mathrm{g}$ LipL-rLimL complex.

\begin{tabular}{|lcc|}
\hline Addition & $\begin{array}{c}\text { Lipase } \\
\text { activity } \\
{\text { units } \mathbf{~ m g}^{-1} \text { ) }}\end{array}$ & $\begin{array}{c}\text { Activation } \\
(\text {-fold })\end{array}$ \\
\hline No lysate & 14 & $(1 \cdot 0)$ \\
Crude cell-free lysate & 27 & $1 \cdot 9$ \\
Dialysed lysate & 16 & $1 \cdot 2$ \\
$<30000$ lysate & 28 & $2 \cdot 0$ \\
$<3000$ lysate & 29 & $2 \cdot 1$ \\
$<3000$ lysate (proteinase treated) & 27 & $1 \cdot 9$ \\
$<3000$ lysate (amylase treated) & 28 & $2 \cdot 0$ \\
$<3000$ lysate (glucoamylase treated) & 26 & $1 \cdot 9$ \\
$<3000$ lysate (phosphatase treated) & 26 & $1 \cdot 9$ \\
$<3000$ lysate (lipase treated) & 30 & $2 \cdot 1$ \\
$<3000$ lysate (37 $\left.{ }^{\circ} \mathrm{C}\right)$ & 20 & $1 \cdot 4$ \\
$<3000$ lysate (1 M HCl treated) & 27 & $1 \cdot 9$ \\
$<3000$ lysate (1 M NaOH treated) & 26 & $1 \cdot 9$ \\
$<3000$ lysate (boiled) & 15 & $1 \cdot 1$ \\
\hline
\end{tabular}

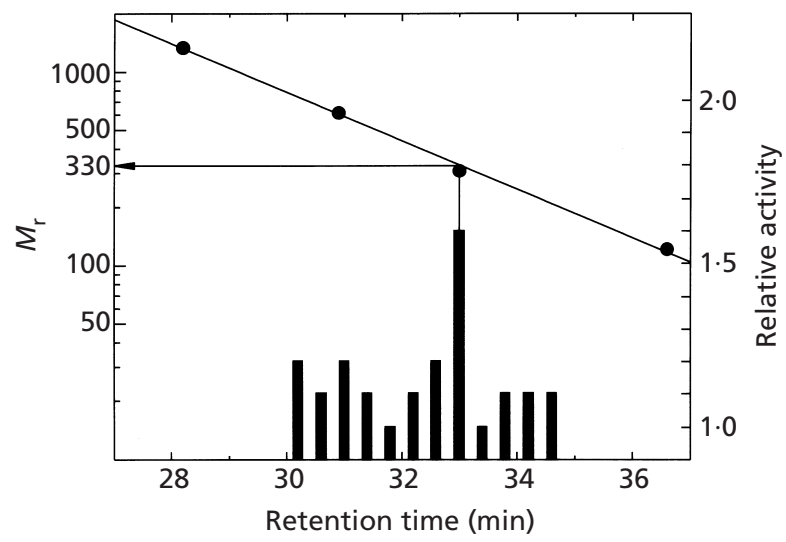

Fig. 2. $M_{\mathrm{r}}$ determination of LAF by gel-filtration HPLC. Filtrate $(250 \mu \mathrm{l})$ from $M_{\mathrm{r}} \geqslant 3000$ ultrafiltration (<3000 lysate) was separated on a Superdex Peptide column $(1.0 \mathrm{~cm} \times 30 \mathrm{~cm}$, Pharmacia-Biotech) into fractions of $200 \mu \mathrm{l}$, and each fraction was assayed for lipase activation (vertical bars, right scale). Substance $\mathrm{P}\left(M_{\mathrm{r}}\right.$ 1347.6), glutathione (oxidized form, $\left.M_{\mathrm{r}} 612 \cdot 6\right)$, glutathione (reduced form, $M_{r}$ 307.3) and cysteine $\left(M_{r}\right.$ 121.2) were used as $M_{\mathrm{r}}$ markers. The $M_{\mathrm{r}}$ of LAF was estimated from a $\log \left(M_{\mathrm{r}}\right)$ versus retention time plot (०, left scale).

sufficiently remove low- $M_{\mathrm{r}}$ compounds from the lysate. Using centrifugation-forced ultrafiltration, both filtrates $(<3000$ lysate and $<30000$ lysate) showed the same level of lipase activation as that of the whole cell-lysate (Table 1), indicating that LAF is a low- $M_{\mathrm{r}}$ compound.

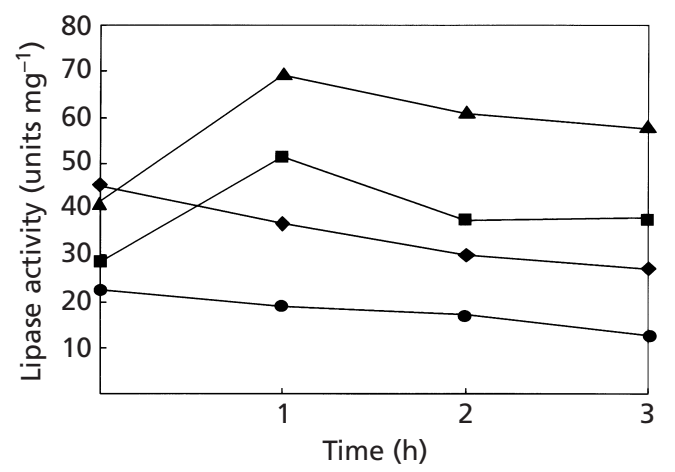

Fig. 3. Additive effect of $\mathrm{LAF}$ and $\mathrm{Ca}^{2+}$ ions on the activation of the rLipL-rLimL complex. The rLipL-rLimL complex was

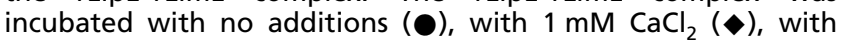
$<3000$ lysate $(\boldsymbol{\square})$, or with $1 \mathrm{mM} \mathrm{CaCl} 2$ and $<3000$ lysate $(\boldsymbol{\Delta})$.

LAF in the $<3000$ lysate was resistant to proteinase, amylase, glucoamylase, phosphatase and lipase (Table 1). LAF was stable under acid or alkaline conditions, but was heat labile. The hydrophilic nature of LAF is indicated by the fact that it was not extracted by organic solvents (hexane, $\mathrm{CH}_{2} \mathrm{Cl}_{2}$, ethyl acetate), nor was it retained on a $\mathrm{C}_{18}$ reverse-phase column with water as mobile phase. Although LAF was weakly retained on a strong anion-exchange column (such as Dowex 1), recovery of LAF activity was very low (less than $10 \%$ ), which prevented further purification. 
(a)

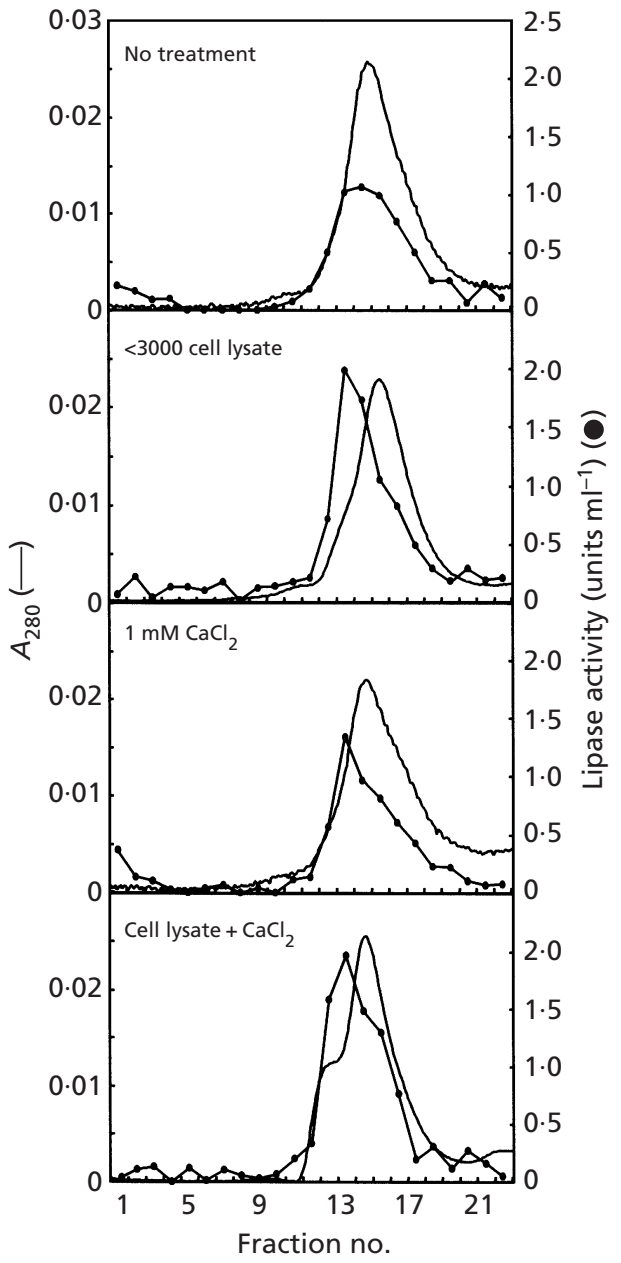

(b)

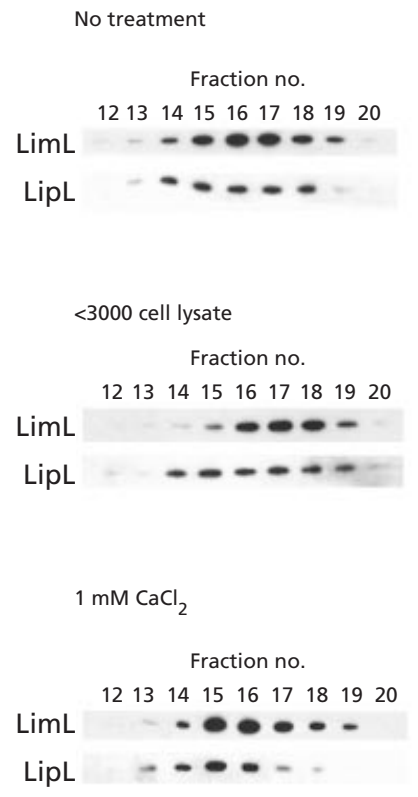

Cell lysate $+\mathrm{CaCl}_{2}$ Fraction no. 121314151617181920

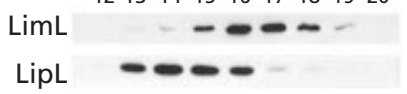

Fig. 4. Effects of $L A F$ and $\mathrm{Ca}^{2+}$ ions on the dissociation of the rLipL-rLimL complex. (a) Filtrate $(10 \mu \mathrm{l})$ from 10 -fold concentrated rLipL-rLimL complex, incubated with or without $<3000$ lysate or $1 \mathrm{mM} \mathrm{CaCl} 2$ for $2 \mathrm{~h}$, was separated on a Superose 12 column $(0.32 \times 30 \mathrm{~cm}$, Pharmacia Biotech). Each fraction $(25 \mu \mathrm{l})$ was assayed for lipase activity. (b) Western blot analysis of fractions 12-20 from the Superose 12 column.
To determine its $M_{\mathrm{r}}$ more precisely, the $<3000$ lysate was separated by gel-filtration HPLC using a Superdex Peptide column (Fig. 2). Only factors eluting from $32.8 \mathrm{~min}$ to $33.2 \mathrm{~min}$ corresponding to $M_{\mathrm{r}} 330 \pm 30$ from a $\log \left(M_{\mathrm{r}}\right)$ versus retention time plot showed lipaseactivation activity. Therefore, it can be concluded that the LAF of Pseudomonas sp. strain 109 is a negatively charged, hydrophilic compound(s) of $M_{\mathrm{r}} 330 \pm 30$.

\section{Synergistic effect of LAF and $\mathrm{Ca}^{2+}$}

Although the activation by LAF and that by $\mathrm{Ca}^{2+}$ were observed to be different, activation by LAF was synergistic with $\mathrm{Ca}^{2+}$ (Fig. 3). When the rLipL-rLlmL complex was incubated with $<3000$ lysate in the presence or absence of $\mathrm{Ca}^{2+}$, the activity observed in the presence of $\mathrm{Ca}^{2+}$ was 1.8 fold higher than that in the absence of $\mathrm{Ca}^{2+}$. Addition of $1 \mathrm{mM} \mathrm{CaCl}_{2}$ was sufficient for maximum activation in these experiments: no additional increase was observed with higher $\mathrm{Ca}^{2+}$ concentrations, such as $5 \mathrm{mM}$ (data not shown). Although the mechanism is unclear at present, LAF seems to stabilize the $\mathrm{Ca}^{2+}$-activated form of lipase.

\section{Dissociation of free rLipL from the rLipL-rLimL complex by LAF}

We propose that LAF enhances lipase activity from the rLipL-rLimL complex by dissociation of free rLipL from the complex. To confirm this, the LAF-activated rLipL-rLimL complex was analysed by molecular-sieve HPLC using a Superose 12 column on a SMART system that was designed to separate and recover microgram quantities of protein (Fig. 4). After a $2 \mathrm{~h}$ activation at $30{ }^{\circ} \mathrm{C}$ with or without $<3000$ lysate, $30 \mu \mathrm{g}$ of the complex was injected and separated into $25 \mu$ fractions. Although the elution profiles of proteins at $280 \mathrm{~nm}$ looked very similar, the elution profiles of lipase activities were different. Lipase activity from the sample without $<3000$ lysate eluted from $43.4 \mathrm{~min}$ to $59.4 \mathrm{~min}$ (fractions 11-21) with a maximum at $53.4 \mathrm{~min}$ (fraction 16 ), and followed the $A_{280}$ profile. Western blot analysis of each fraction revealed that these lipase-active fractions contained both rLipL and rLimL in a ratio of $1: 1$, indicating that they represented the rLipL-rLimL complex. Under the gel-filtration conditions, native LipL elutes in fractions 14-15 (i.e. with a higher $M_{\text {r }}$ than expected, probably because the protein is in complex 
with the detergent present in the column buffer) and rLimL elutes in fractions 18-19 (data not shown). In the sample incubated with $<3000$ lysate, peak lipase activity eluted earlier, in fraction 14, before the main protein peak. These fractions (fractions 14 and 15) contained a higher LipL : LimL ratio. Incubation of the rLipL-rLimL complex with $\mathrm{Ca}^{2+}$ alone resulted in peak lipase activity in fractions 14-15 but showed no dissociation of rLipL when the fractions were assayed with antibodies, while incubation with both $<3000$ lysate and $\mathrm{Ca}^{2+}$ resulted in $2 \cdot 0$-fold higher absorption area in fractions $13-15$ than that of the sample with $<3000$ lysate alone. The $2 \cdot 0$-fold higher absorption area agreed well with the $1 \cdot 8$-fold increase of lipase activity and suggested the increase of free rLipL, as confirmed by Western blot analysis. These results indicate that coexistence of $\mathrm{Ca}^{2+}$ stimulated the LAF-dependent dissociation of free LipL from the rLipL-rLimL complex, although the mechanism by which $\mathrm{Ca}^{2+}$ has its effect is not clear at present.

\section{Conclusions}

We have demonstrated that two low- $M_{\mathrm{r}}$ factors $\left(\mathrm{Ca}^{2+}\right.$ ions and natural LAF from Pseudomonas sp. strain 109) act on a rLipL-rLimL complex to increase lipase activity. Although the structure of LAF has not been identified, it is a hydrophilic and proteinase-resistant compound(s) of $M_{\mathrm{r}} 330 \pm 30$, and its major role in lipase activation is as a stimulator of rLipL dissociation. $\mathrm{Ca}^{2+}$ alone did not cause rLipL dissociation but it stimulated the LAF-dependent rLipL dissociation.

\section{ACKNOWLEDGEMENTS}

This research was supported in part by the grant from the Nisshin Seifun Foundation.

\section{REFERENCES}

Frenken, L. G. J., Bos, J. W., Visser, C., Muller, W., Tommassen, J. \& Verrips, C. T. (1993a). An accessory gene, $l i p B$, required for the secreted lipase of Pseudomonas glumae lipase. Mol Microbiol 9, 579-589.

Frenken, L. G. J., Groot, A., Tommassen, J. \& Verrips, C. T. (1993b). Role of the $l i p B$ gene product in the folding of the secreted lipase of Pseudomonas glumae. Mol Microbiol 9, 591-599.

Hirayama, N. O., Yoshikawa, K., Nishioka, T. \& Oda, J. (1993). Lipase from Pseudomonas aeruginosa. Eur J Biochem 215, 239-246.

Hobson, A. H., Buchley, C. M., Aamand, J. L., Jørgensen, S. T., Diderichsen, B. \& McConnell, D. J. (1993). Activation of bacterial lipase by its chaperone. Proc Natl Acad Sci USA 90, 5682-5686.
Ihara, F., Kageyama, Y., Hirata, M., Nihira, T. \& Yamada, Y. (1991). Purification, characterization, and molecular cloning of lactonizing lipase from Pseudomonas species. J Biol Chem 266, 18135-18140.

Ihara, F., Okamoto, I., Nihira, T. \& Yamada, Y. (1992). Requirement in trans of the downstream limL gene for activation of lactonizing lipase from Pseudomonas sp. 109. J Ferment Bioeng 73, 337-342.

Ihara, F., Okamoto, I., Akao, K., Nihira, T. \& Yamada, Y. (1995). Lipase modulator protein (LimL) of Pseudomonas sp. strain 109. J Bacteriol 177, 1254-1258.

lizumi, T., Nakamura, K., Shimada, Y., Sugihara, A., Tominaga, Y. \& Fukase, T. (1991). Cloning, nucleotide sequencing, and expression in Escherichia coli of a lipase and its activator genes from Pseudomonas sp. KWI-56. Agric Biol Chem 55, 2349-2357.

lizumi, T. \& Fukase, T. (1994). Role of the gene encoding lipase activator from Pseudomonas sp. strain KWI-56 in in vitro activation of lipase. Biosci Biotechnol Biochem 58, 1023-1027.

Jørgensen, S. T., Skov, K. W. \& Diderichsen, B. (1991). Cloning, sequence, and expression of a lipase gene from Pseudomonas cepacia: lipase production in heterologous hosts requires two Pseudomonas genes. J Bacteriol 173, 559-567.

Keller-Schierlein, W. (1973). Chemie der Makrolid-Antibiotica. Fortschr Chem Org Naturst 30, 313-460.

Kok, R. G., van Thor, J. J., Nugteren-Roodzant, I. M., Vosman, B. \& Hellingwerf, K. J. (1995). Characterization of lipase-deficient mutants of Acinetobacter calcoaceticus BD413: identification of a periplasmic lipase chaperone essential for the production of extracellular lipase. J Bacteriol 177, 3295-3307.

Makita, A., Nihira, T. \& Yamada, Y. (1987). Lipase catalysed synthesis of macrocyclic lactones in organic solvent. Tetrabedron Lett 28, 805-808.

Ogierman, M. A., Failarimo, A., Riess, T., Williams, S. G., Attridge, S. R. \& Manning, P.A. (1997). Characterization of the Vibrio cholerae El Tor lipase operon $\operatorname{lip} A B$ and a protease gene downstream of the hly region. J Bacteriol 179, 7072-7080.

Siomi, M. C., Yoshikawa, K., Hirayama, N. O., Yamamoto, K., Sogabe, Y., Nakatani, T., Nishioka, T. \& Oda, J. (1992). Purification, molecular cloning, and expression of lipase from Pseudomonas aeruginosa. Arch Biochem Biophys 296, 505-513.

Studier, F. W., Rosenberg, A. H., Dunn, J. J. \& Dubendorff, J. W. (1990). Use of RNA polymerase to direct expression of cloned genes. Methods Enzymol 185, 60-89.

Wohlfarth, S. \& Winkler, U. K. (1992). Molecular genetics of the extracellular lipase of Pseudomonas aeruginosa PAO1. J Gen Microbiol 138, 1325-1335.

Wong, C. \& Whitesides, G. M. (1994). Enzymes in Synthetic Organic Chemistry, pp. 70-108. Amsterdam: Elsevier.

Zaks, A. \& Klibanov, A. M. (1984). Enzymatic catalysis in organic media at $100{ }^{\circ} \mathrm{C}$. Science 224, 1249-1251.

Zaks, A. \& Klibanov, A. M. (1985). Enzyme-catalyzed processes in organic solvents. Proc Natl Acad Sci USA 82, 3192-3196.

Received 29 January 1999; revised 19 April 1999; accepted 7 June 1999. 